\title{
Environmental perspectives of Phragmites australis (Cav.) Trin. Ex. Steudel
}

\author{
Jatin Srivastava $\cdot$ Swinder J. S. Kalra $\cdot$ \\ Ram Naraian
}

Received: 26 May 2013/ Accepted: 18 November 2013/Published online: 3 December 2013

(c) The Author(s) 2013. This article is published with open access at Springerlink.com

\begin{abstract}
Extensive research is being conducted worldwide to find alternative and efficient systems to lessen the impacts of climate change and reduce environmental pollution. The genus Phragmites has proven ability to mitigate the environmental pollution of its surroundings. Common reed (Phragmites australis (Cav.) Trin. Ex. Steudel), a graminaceous plant of cosmopolitan nature, has been extensively studied especially for the mitigation of environmental contamination. The capability of common reed to grow well at extreme environmental conditions such as elevated $\mathrm{CO}_{2}$ and high temperature is conferred by several factors such as change of carbon trapping mechanism (from $\mathrm{C}_{3}$ to $\mathrm{C}_{4}$ and vice versa), microbial association and biochemical adaptations. $P$. australis has been a most preferred unique plant system, especially in ecological engineering for improving the quality of wastewater. This paper reviews the current state of knowledge regarding the suitability of Phragmites australis for environmental
\end{abstract}

\section{J. Srivastava}

Department of Applied Sciences, Global Group of Institutions, NH-24B, Raebareli Road, Lucknow, UP, India

J. Srivastava $(\square)$

Department of Applied Sciences, Himalayan Institute of Technology and Management, NH-24, Sitapur Highway, Lucknow, UP, India

e-mail: jks_345@rediffmail.com

\section{S. J. S. Kalra}

Department of Chemistry, Dayanand Anglo Vedic College, Civil Lines, Kanpur, UP, India

\section{R. Naraian}

Department of Biotechnology, V.B.S. Poorvanchal University, Jaunpur, UP, India remediation and summarizes recent advancements in our understanding of this grass.

Keywords Phragmites australis · Environmental contamination $\cdot \mathrm{C}_{3} \cdot \mathrm{C}_{4} \cdot$ Ecological engineering

\section{Introduction}

The genus Phragmites of family Poaceae comprises of the most common perennial, rhizomatous, stoloniferous and tall (2.0-6.0 m) grasses, viz., Phragmites australis, P. karka, $P$. communis, $P$. longivalvis, $P$. maxima and $P$. prostrata (Poonawala et al. 1999), of temperate and tropical wetlands all over the world. P. australis (common reed) and P. karka (flute grass) are two commonly occurring members on the Indian sub-continent. The geographical distribution of Phragmites spp. extends from cold temperate regions to the wetlands of hot and moist tropics (Lessmann et al. 2001), although the transitional zones (ecotones) of rivers, big lakes and wetlands are the most preferred habitats of the common reed (Kenneth and Biddlestone 1995). P. australis seeds profusely and spreads vegetatively by a vigorous system of rhizomes and stolons (Hara et al. 1993; Marks et al. 1994) rendering it cosmopolitan in nature. Figure 1 show the global distribution of the genus Phragmites. The competitive nature of $P$. australis reflects the plant's adaptive features. Studies show that $P$. australis grows in soils of different $\mathrm{pH}$, salinity, fertility and textures, and attains high productivity under different climatic conditions (Dinka and Szeglet 1998). Voluminous literature is available on the ecological significance of Phragmites (Marks et al. 1994; Coops et al. 1996; Brix 1999; Clevering and Lissner 1999; Meyerson et al. 2000; Clevering et al. 2001; Ostendorp et al. 2003; Häfliger et al. 2006; Nechwatal et al. 


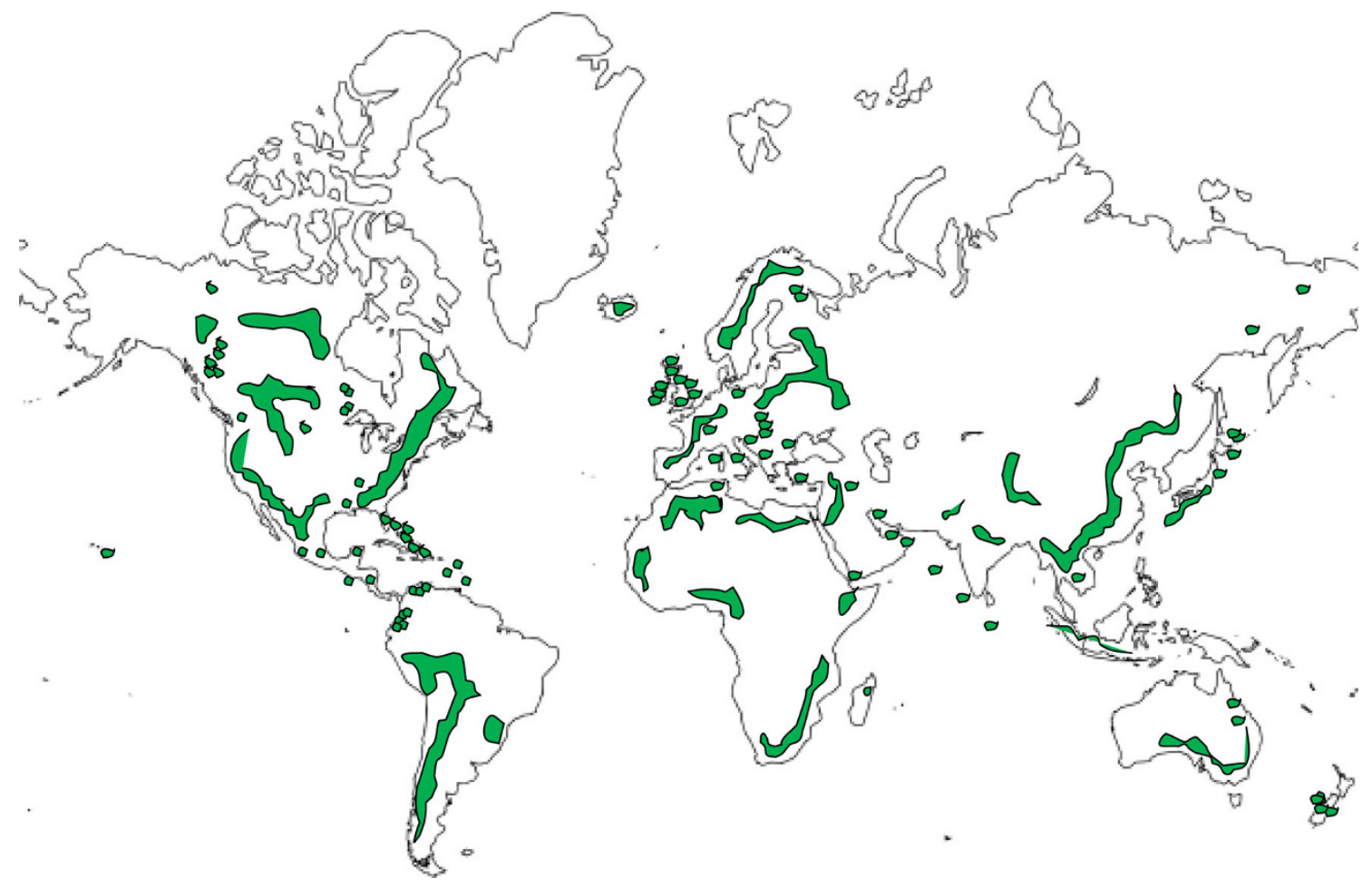

Fig. 1 World map showing the distribution of Phragmites australis over the continents. Green strips show the global infestation of Phragmites australis. The infestation map shows only those identified

2008; Weidenhamer et al. 2013). The use of Phragmites species in India is conventional, primarily as raw material for rayon and paper pulp (Poonawala et al. 1999). Species of genera Phragmites, chiefly australis, karka and communis, are well documented for their ability to mitigate environmental pollution (Singh and Srivastava 2007; Srivastava 2008; Srinivasan et al. 2000). Phragmites australis has been the most preferred plant among the ecological engineers for its application in constructed wetlands (Kadlec and Knight 1996; Brix et al. 2003; Garcia et al. 2004; Vymazal and Kröpfelova 2005; Wang et al. 2010). In this review paper, comprehensive ecological and environmental applications of Phragmites australis (common reeds) have been reviewed to understand the use of this grass in environmental protection engineering with a summary of recent advancements in our understanding.

\section{Ecology of Phragmites australis (Cav.) Trin. Ex. Steudel}

An adaptive amphibious species

Phragmites australis is a transitional species of two closely attached ecosystems, viz., aquatic and terrestrial, and commonly occurs in marshy wetlands (Mal and Narine 2004). The ecological significance of $P$. australis has been regions on the earth where the species $P$. australis has been reported; however, species other than $P$. australis may also be present

realized worldwide and it is a well-known environmentally resilient species. The growing period is long in most of the subtropical and mild temperate zones, facilitating reed plants to obtain all the essential adjustments to the variations in temperature, soil nutrients and available oxygen (wetlands) together with certain physiological features such as transpiration rates in connection to the seasonal variations (Haslam 1972). The rhizomes of $P$. australis are highly preserved as these remain buried in the soil and sediments, which help provide protection from frost and fire. The rhizomes do not survive in anaerobic conditions as a result of long flooding (Ostendorp et al. 2003), indicating shorter growth length in such conditions. The disappearance of rhizomes of $P$. australis under flooded conditions has also been observed and are found to be completely replaced by adventitious roots (Srivastava 2008). In anaerobic conditions as a result of inundation, the expression of anaerobic stress proteins (ANPs) enables oxygen-independent energy generation in the common reed plants through metabolic processes, a common feature of most of the plant systems growing in anoxic conditions (Subbaiah and Sachs 2003). High transpiration rate of $P$. australis growing under floodlike conditions display an adaptive feature, protecting it from waterlogging especially in summers and at mild temperate regions (Borin et al. 2011). Figure 2 shows the general biological attributes of $P$. australis. 


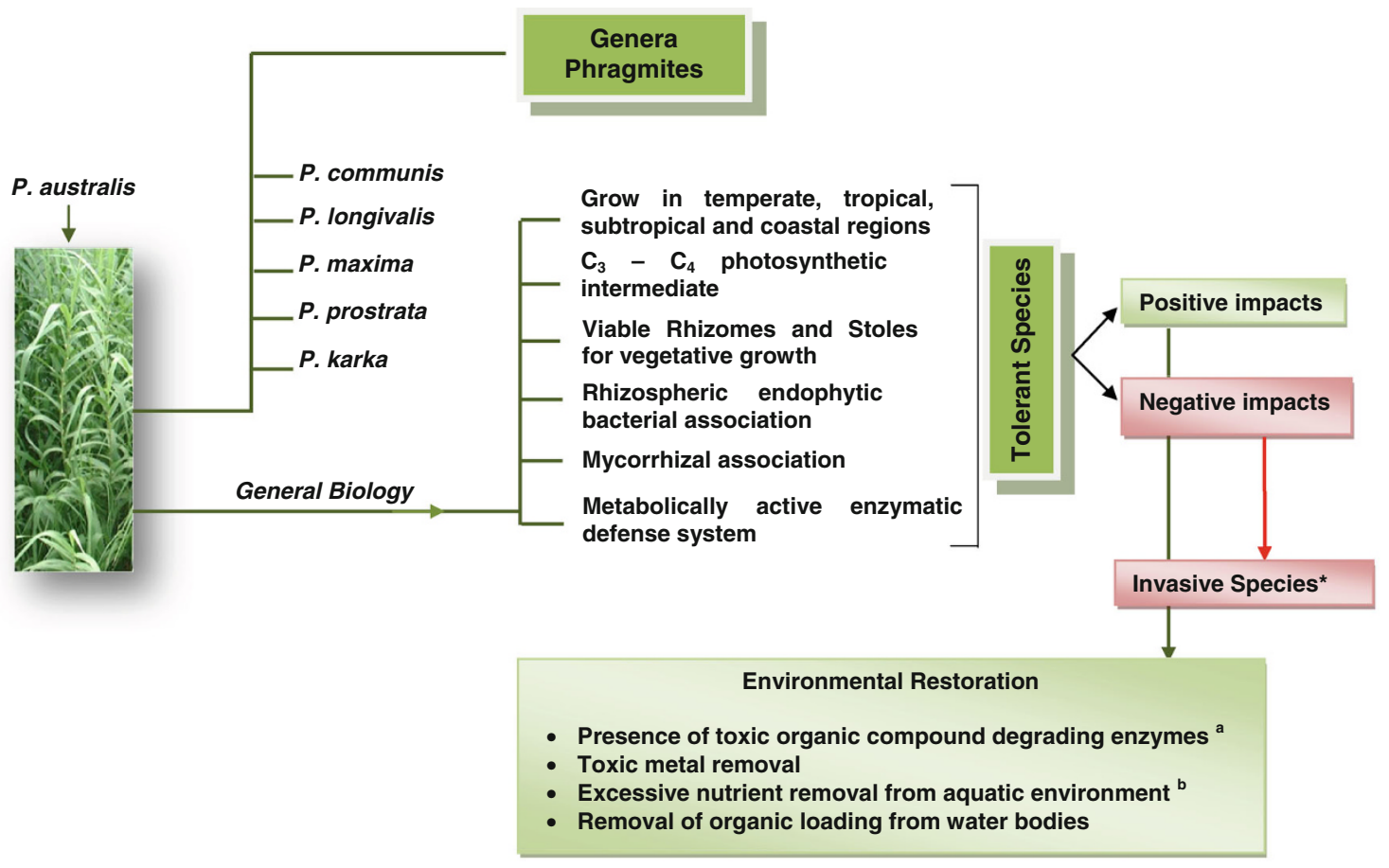

Fig. 2 General attributes of Phragmites australis (Cav.) Trin. Ex. Steudel. Six species of genus Phragmites have been reported so far (Poonawala et al. 1999); out of these six, P. australis is cosmopolitan. a (Chu et al. 2006); b (Brix et al. 2003). Asterisk invasions by
Phragmites species have been reported in northeastern USA, Europe and Australia, but no report of such invasion is available from the rest of the world. However, the introduction of this grass from Europe to the world countries cannot be overlooked
Photosynthetic intermediate

P. australis is a $\mathrm{C}_{3}$ plant; however on the basis of habitats, four $\mathrm{C}_{3}-\mathrm{C}_{4}$ photosynthetic intermediate ecotypes are known, viz., $\mathrm{C}_{3}, \mathrm{C}_{4}$ species that evolve in swamp; $\mathrm{C}_{3}-\mathrm{C}_{4}$ intermediate ecotype; $\mathrm{C}_{3}$ species that evolve in dry land; and $\mathrm{C}_{3}-\mathrm{C}_{4}$ intermediate ecotype in saline environment have been reported by Zheng et al. (2000). Having both $C_{3}$ and $\mathrm{C}_{4}$ type of photosynthesis in plants allows them to compete better to the changing environmental conditions (Srivastava et al. 2012). Switching to the $\mathrm{C}_{4}$ photosynthetic mechanism renders to $P$. australis perfect protection necessary to survive in extreme environments. This may be one of the factors responsible for the global occurrence of $P$. australis. A detailed discussion of tolerance imparted through the photosynthetic intermediates has been included later in this review.

\section{Microbial association}

The root zone of $P$. australis is rich in dissolved oxygen as well as in organic carbon, providing optimal conditions required for microbial colonization. Mycorrhizal ecotypes of $P$. australis have also been reported (Oliveira et al. 2001), although mycorrhization (mostly by the members of the Glomeraceae family, e.g., Glomus fasciculatum,
Glomus mosseae) is altered significantly depending on the soil moisture and temperature conditions. Mycorrhization generally helps establish plants in extremely disturbed sites (Oliveira et al. 2001). P. australis grows well on drying sedimentation ponds, polluted river banks, quarried fields and other disturbed sites (Roman et al. 1984) and at extreme saline conditions (Al-Garni 2006). The rhizosphere of $P$. australis contains a variety of aerobic microbes (Chaturvedi et al. 2006), e.g., Microbacterium hydrocarbonoxidans, Achromobacter xylosoxidans and a number of species belonging to the genera Bacillus and Pseudomonas. In general, most bacterial species of the rhizospheric microbial community act as plant growth promoters (PGP), especially in wetland plant species. Okabe et al. (2012) reported the presence of Nitrosomonaslike ammonia oxidizing bacteria $(\mathrm{AOB})$, indicating that nitrification occurs under waterlogged conditions. Li et al. (2013) reported specific root zone-associated microbial community including Acidobacteria, Actinobacteria, Nitrospirae and Spirochaetes in P. australis.

Salt enrichment and $P$. australis

Germination of many wetland species is influenced by salinity, temperature and light at the surface (Ekstam et al. 1999). Seeds of $P$. australis germinate under a broad range 
Table 1 Characteristics of $\mathrm{C}_{3}$ and $\mathrm{C}_{4}$ plants under altered climatic conditions, clearly defining the strategies of plants to survive under extreme environment

\begin{tabular}{|c|c|c|c|}
\hline Response parameters & $\begin{array}{l}\mathrm{C}_{3} \text { under elevated } \mathrm{CO}_{2} \\
\text { and temperature }\end{array}$ & $\begin{array}{l}\mathrm{C}_{4}-\text { under elevated } \mathrm{CO}_{2} \\
\text { and temperature }\end{array}$ & References \\
\hline Photosynthetic activity & Cold conditions preferred & Higher temperature resistant & Weber and Caemmerer 2010; Ueno 2001 \\
\hline Photorespiration & Can exceed $30 \%$ & Hardly achieve $5 \%$ & Sage 2004 \\
\hline Light use efficiency & Lesser & Greater & Bräutigam and Hoffmann-Benning 2008; Evans 1993 \\
\hline Biomass (gm dry wt.) & Slightly $<\mathrm{C}_{4}(33 \%)$ & Slightly $>\mathrm{C}_{3}(44 \%)$ & Sage 2004; Wand et al. 1999 \\
\hline Mycorrhization & Lesser & Higher & Tang et al. 2009; Treseder 2004 \\
\hline Water use efficiency & Less efficient & Highly efficient & Derner et al. 2003; Winslow et al. 2003 \\
\hline Nitrogen use efficiency & Less efficient & Highly efficient & Niu et al. 2006; Edwards et al. 2005 \\
\hline Stomatal conductance & High & Lower & Caird et al. 2007 \\
\hline
\end{tabular}

From (Srivastava et al. 2012)

of conditions (Greenwood and MacFarlane 2006). Reeds are facultative halophytes (Saltonstall 2002) that grow well in high salinity up to $30 \%$ (Asaeda et al. 2003) and accumulate amino acids and sugars to maintain the osmotic potential and cell turgor (Hartzendorf and Rolletschek 2001). High $\mathrm{K}^{+}$concentration in leaf tissue, an important factor for salt tolerance (Lissner et al. 1999), is mediated by $\mathrm{K}^{+}$transporters resulting in high $\mathrm{K}^{+} / \mathrm{Na}^{+}$ratio (Takahashi et al. 2007). This is largely influenced by $\mathrm{Ca}^{+}$ions in $P$. australis, whereby calcium ion accumulation increases the $\mathrm{K}^{+} / \mathrm{Na}^{+}$ratio, thus imparting tolerance to the plant for salt stress depending on the increased water potential and stomatal conductance (Pagter et al. 2009; Gorai et al. 2010). In conclusion, $P$. australis is a well-equipped plant with physiological characteristics to manage its own sustenance in stressful environments.

Understanding the tolerance of $P$. australis

$P$. australis has a unique adaptive feature to withstand hostile environment. Unique photosynthesis ability of Phragmites (as mentioned in "Photosynthetic intermediate" section), attributable to its $\mathrm{C}_{3}-\mathrm{C}_{4}$ intermediate characteristic (although $P$. australis preferably follows $\mathrm{C}_{3}$ pathway) and because of mono-specific stands (as a result of vegetative reproduction) out-compete native vegetation (Kettenring et al. 2010). Table 1 shows some of the characters of $\mathrm{C}_{3}$ and $\mathrm{C}_{4}$ plants growing in altered climatic conditions. Switching over from $\mathrm{C}_{3}$ to $\mathrm{C}_{4}$ mechanism helps trap atmospheric carbon dioxide $\left(\mathrm{CO}_{2}\right)$ most efficiently, supporting carbohydrate allocation to the rhizomes. Stored carbohydrates in the rhizomes ensure the survival of plant and maintenance of root-associated endophytic bacterial community (Li et al. 2010) and mycorrhiza during extreme environmental conditions. In addition, oxygen transport from above to belowground plant parts via aerenchymatous tissues ensures the survival of aerobic microbial

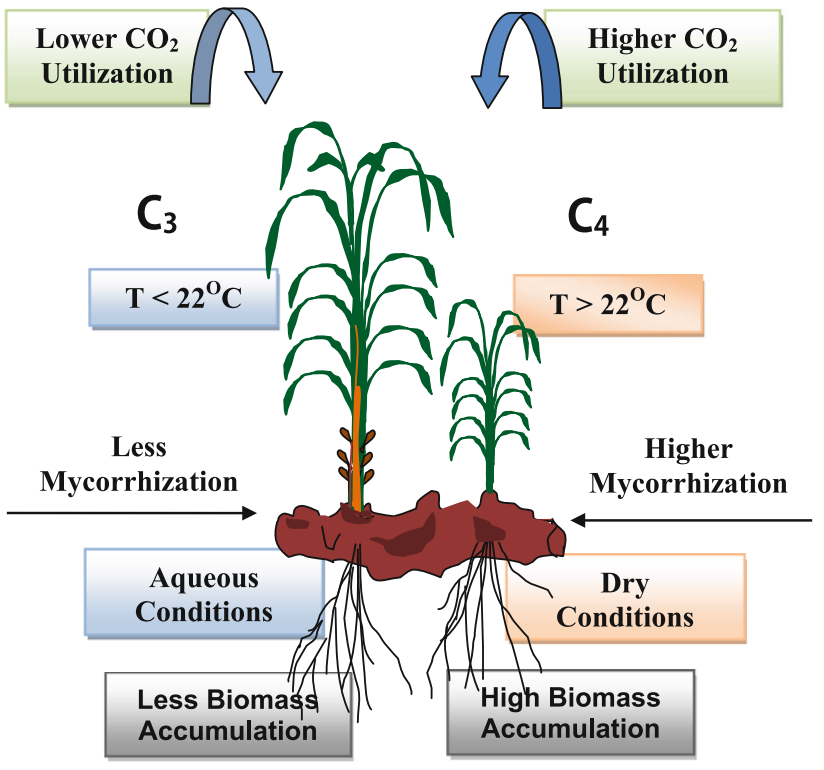

Fig. 3 The $\mathrm{C}_{3}-\mathrm{C}_{4}$ ecotype of $P$. australis and its survival strategies

communities associated with the roots. $P$. australis maintains carbon content in the rhizosphere as a result of root exudates containing phenols, short-chained organic acids, sugars and amino acids. This is the sole source of carbon to the Mycobacterium spp. capable of degrading toxic organic compounds such as benzo[a]pyrene (Toyama et al. 2011a). Toyama et al. (2011b) reported that bacterial species, viz., one strain of Stenotrophomonas sp. and two strains of Sphingobium spp. isolated from the rhizosphere, were found to have reducing ability for toxic organic compounds such as 4-tert-octylphenol. Figure 3 shows the survival strategy of $P$. australis in two types of environmental conditions, viz. moist and cold and warm and dry. However, for optimal growth, common reed being a hydrophyte needs plenty of water availability (Winslow et al. 2003). At higher atmospheric temperature, senescence caused the 
death of $\mathrm{C}_{3}$ plants because of reduced $\mathrm{CO}_{2}$ fixation and increased respiration; however, $\mathrm{C}_{3}-\mathrm{C}_{4}$ intermediate ecotypes of $P$. australis can tolerate such conditions. Mycorrhizal association in $P$. australis also helps tolerate high salinity as it prevents water loss significantly (Al-Garni 2006). Many wetland species exhibiting radial oxygen loss show the unique feature of iron plaque being deposited on mature parts of their roots (St-Cyr and Crowder 1988) reducing the chances of toxic metal absorption through diffusion (Greipsson 1994). P. australis is a wetland species and has been reported to have iron plaque of Fe III on its root surface (only when growing in an iron-rich condition) and a lignified, suberized rhizodermal cell layer protecting roots from noxious substances causing reduced oxygen level at root zone (Batty et al. 2000). It also protects root tissues from the toxic effects of intruding metals such as $\mathrm{Cu}$, although to a lesser extent (Ali et al. 2002). Moreover, faster growth and higher biomass accumulation help $P$. australis tolerate the toxic effects of metals and other toxicants (Bragato et al. 2006). Evapotranspiration (ET) rates are high in $P$. australis which also helps protect plants under inundation (Borin et al. 2011) during floodlike conditions (Ostendorp et al. 2001); however, strong flooding can cause damage by separating leaves from the air supply. If a sufficient part of the leaves remain in contact with the air, the reeds survive. Reed plants are also able to survive in low pH conditions (Haslam 1972; Nixdorf et al. 2001) as the roots and rhizomes are largely protected by hypodermal thickening of lignin and wax on the surface, preventing the penetration of undissociated organic acids at low $\mathrm{pH}$, which are lethal because such chemicals pass through biological non-polar membranes. Moreover, the root exudates contain $\mathrm{HCO}_{3}{ }^{1-}$ ions that provide buffering to the milieu interior. ET is also associated with the tolerance of this plant against toxic metals by releasing water-containing metal ions through the leaves (Windham et al. 2001).

\section{Environmental restoration by $P$. australis}

Removal of nutrients and organic compounds

from polluted water

The influx of nutrient ions such as phosphate, nitrate, potassium and calcium from the non-point sources, especially through lateral diffusion, is significant on the shores of natural water systems causing enrichment of water and impairment of water quality (Knight et al. 2000; Srivastava et al. 2011). Approximately, $60 \%$ of the input of inorganic nitrogen into the water is estimated to be due to human activities such as human settlements (sewage) and agriculture (Nimptsch and Pflugmacher
2007). P. australis has an important role in mitigating this water pollution. It has been the most preferred research plant for pollution mitigation from wastewaters, especially in engineered wetlands. $P$. australis accumulates almost twice as high concentration of phosphorus $\left(\mathrm{PO}_{4}{ }^{3-}\right)$ and potassium in the below and aboveground plant parts as compared to other emergent macrophytes, which help to remove excessive nutrient ions from environmental matrices (Singh and Srivastava 2007). $P$. australis maintains constant oxygenation of the rhizosphere resulting in the oxidation of ammonia $\left(\mathrm{NH}_{3}\right)$ to nitrate $\left(\mathrm{NO}_{3}{ }^{-}\right)$(Brix et al. 2003). P. australis is also capable of degrading organo-chlorine compounds such as DDT and polychlorinated biphenyls (PCBs), which is partially mediated by enzymes like peroxidase and plant P-450 system (Chu et al. 2006). Voluminous literature (Brix and Schierup 1990; Cooper 1999; Greenway and Wooley 1999; da-Motta-Marques et al. 2001; Peltier et al. 2003; Brix et al. 2003; Solano et al. 2004; Toet et al. 2005; Bragato et al. 2006; Mant et al. 2006; Lee and Scholz 2007, Bianchi et al. 2011) and the references therein are available on various aspects of pollution and excessive nutrient removal through $P$. australis. For the treatment of industrial wastewater (Cooper et al. 1996) and urban wastewater (Srinivasan et al. 2000), Phragmites spp. have been widely used in constructed wetlands (Scholz and Xu 2002; Scholz 2003; Stottmeister et al. 2003; Kaseva 2004; Solano et al. 2004; Srivastava et al. 2008) for the treatment of the most common parameter, 5 day BOD; however, the findings show a negative correlation with $P$. australis which is the only cost-effective stand-alone treatment of raw wastewater.

\section{Removal of heavy metals}

Removal of toxic heavy metals from the aquatic environment is one of the priorities of the environmentalist all over the world. P. australis is one of the most studied aquatic plants for heavy metal removal (Schierup and Larsen 1981; Szymanowska et al. 1999; Ye et al. 2003; Samecka-Cymerman and Kempers 2001; Peltier et al. 2003; Windham et al. 2001; Ali et al. 2002; Mant et al. 2006; Chiu et al. 2006; Drzewiecka et al. 2010) because of its high metal removal potential (Table 2) and fast growth, accumulating metal in above and belowground biomass. In general, plants have a tendency to release excessive metal ions through transpiration, reducing the toxic concentration in the plant tissues of leaves which is common to $P$. australis also (Berk and Colwell 1981; Burke et al. 2000). Since, out of 53 heavy metals, only 17 are bio-available (Carranza-Alvarez et al. 2008), increased transpiration rates increase the bioavailability of metals in P. australis. Valuable findings of Southichak 
Table 2 Environmental tolerance of Phragmites australis
EOT + extent of tolerance, -- not tolerant

\begin{tabular}{|c|c|c|c|c|}
\hline \multirow[t]{2}{*}{ Sr No } & \multirow{2}{*}{$\begin{array}{l}\text { Physicochemical } \\
\text { environment }\end{array}$} & \multicolumn{2}{|c|}{ Tolerance } & \multirow[t]{2}{*}{ References } \\
\hline & & Range & EOT & \\
\hline 1. & Temperature & $0-40{ }^{\circ} \mathrm{C}$ & +++ & Haslam 1972 \\
\hline 2. & Frost & - & +++ & Weisner and Strand 1996 \\
\hline 3. & Drought & - & --- & Takahashi et al. 2007 \\
\hline 4. & Flood & - & --+ & Ostendorp et al. 2003 \\
\hline 5. & $\begin{array}{l}\mathrm{pH} \\
\text { Metals }\end{array}$ & $2.9-8.1$ & +++ & Haslam 1972 \\
\hline 6. & $\mathrm{Cd}$ & & +++ & Wang et al. 2009 \\
\hline 7. & $\mathrm{Cu}$ & & --+ & Ye et al. 2003 \\
\hline 8. & $\mathrm{Zn}$ & & +++ & Peltier et al. 2003 \\
\hline 9. & $\mathrm{Cr}$ & & --+ & Mant et al. 2006 \\
\hline 10. & $\mathrm{Mn}$ & & +++ & Samecka-Cymerman and Kempers 2001 \\
\hline 11. & $\mathrm{Ni}$ & & --+ & Samecka-Cymerman and Kempers 2001 \\
\hline 12. & $\begin{array}{l}\mathrm{Pb} \\
\text { Metalloids }\end{array}$ & & ++- & Drzewiecka et al. 2010 \\
\hline 13. & As & & +++ & Ghassemzadeh et al. 2008 \\
\hline 14. & $\mathrm{Sb}$ & & -++ & Ghassemzadeh et al. 2008 \\
\hline
\end{tabular}

et al. (2006) suggest wide tolerance in the reed against most of the toxic metals such as $\mathrm{Cu}, \mathrm{Ni}, \mathrm{Cd}, \mathrm{Zn}$ and $\mathrm{Pb}$. However, metal removal and accumulation depend largely on the growing period of plants and their physiological attributes (Windham et al. 2001). P. australis can withstand higher concentration $>8.0 \mu \mathrm{M}$ of $\mathrm{Cu}$ (Ali et al. 2002); therefore, it is also considered as a $\mathrm{Cu}$-tolerant plant. Higher accumulation of $\mathrm{Zn}$ and $\mathrm{Mn}$ has been reported in the roots of $P$. australis (Peltier et al. 2003). The studies show the higher removal of metal ions by $P$. australis as compared to the other plant Rhananculus spherosphermus (Aksoy et al. 2005) and by Spartina alterniflora a marsh plant of North America (Weis and Weis 2004) with a decreasing trend of accumulation as roots $>$ rhizome $>$ leaf $>$ stem $\quad$ (Bonanno 2011). As mentioned in "Microbial association", endophytic bacterial community comprising Gram-negative and Grampositive bacterial species present in the tissues and on the surface of reed grass tend to enhance the uptake of metal ions from the environmental matrices, especially water (Li et al. 2010), which also confirm the findings of Keller et al. (1998) according to which most of the metals taken up by the common reed plant remain in rhizomes and roots. Removal of metalloids such as arsenic (As) and antimony $(\mathrm{Sb})$ by the common reed plant has also been reported by Ghassemzadeh et al. (2008). A recent study of Ayeni et al. (2012) showed the abundance of metals in various parts of $P$. australis in the following order: $\mathrm{Al}>\mathrm{Pb}>\mathrm{Cd}>\mathrm{Co}>\mathrm{Ni}>\mathrm{Cr}$ and for micronutrients $\mathrm{Fe}>\mathrm{Mn}>\mathrm{Zn}>\mathrm{Cu}$ depending on the concentration in the environment.

\section{Environmental demerits of $\boldsymbol{P}$. australis}

Methane emission

Phragmites dominate wetlands and provide a significant source of methane emission to the atmosphere (Brix 1999). High $\mathrm{CH}_{4}$ emission rates characterize various wetlands occupied by Phragmites communities with average emission as high as $123 \mathrm{gCH}_{4} \mathrm{~m}^{-2} \mathrm{a}^{-1}$ reported from mesoeutrophic lakes (Kankaala et al. 2004). The emission of $\mathrm{CH}_{4}$ (methane) from wetland soil is a result of two contrasting microbiological processes, viz., anaerobic $\mathrm{CH}_{4}$ production and aerobic $\mathrm{CH}_{4}$ oxidation (Duan et al. 2009); however, oxygen availability and potential for aerobic degradation of organic matter and $\mathrm{CH}_{4}$ oxidation increase when the water table is lowered. The studies indicate the contribution of $P$. australis plant in the emission of global warming-causing gas; however, interestingly $P$. australis being a $\mathrm{C}_{3}-\mathrm{C}_{4}$ intermediate has unique carbon dioxide trapping mechanism reducing the major culprit gas $\left(\mathrm{CO}_{2}\right)$.

\section{$P$. australis an invasive species}

Long historical research records prove $P$. australis to be an invasive species (Mal and Narine 2004; Rudrappa et al. 2007) that invaded from Europe to various parts of the world, especially the eastern part of North America (Saltonstall 2002) and southern Australia. There has been no report of invasion by $P$. australis to Asian countries. Wang et al. (2006) reported the reinvasion by $P$. australis into experimental marshes which was later blocked by 
regenerated native species, especially by Spartina patens; however, $P$. australis has reportedly been suggested to be more successful in replacing another species Spartina alterniflora of the same genera in the lower marshes of eastern USA (Weis and Weis 2004). P. australis invades chiefly via rhizomes and stolons. Rudrappa et al. (2007) reported the presence of gallic acid (3,4,5-trihydroxy benzoic acid), a chemical secreted by the roots of common reeds, caused the cell death of other plants (native species) conferring an invasive nature to $P$. australis, although recently Weidenhamer et al. (2013) reported no such correlation between invasiveness of common reed and gallic acid. As per Weidenhamer et al. (2013), the half-life of gallic acid is less than 1 day, which may not render any negative effect on other plants. The reports of Weidenhamer et al. (2013) indicate no role of gallic acid in imparting the invasive character of this grass as described earlier by Rudrappa et al. (2007).

\section{Future studies}

There are several potential opportunities still open as far as $P$. australis is concerned; for example, eco-physiological evidences for ascertaining the invasive nature of $P$. australis and mechanisms for the invasive character of common reed are still to be confirmed. The performance of $P$. australis in shoreline management at wetlands and in ecological turnover along with several other field studies are required to confirm the pollution mitigation ability of $P$. australis from the environmental matrices, especially under altered climatic conditions. Despite many research reports on the successful use of common reed in constructed wetlands for the treatment of industrial effluent of various nature, pilot-scale studies are still required to ascertain the use of this grass, especially in engineered wetlands in combination with microbial consortia for the treatment of municipal wastewater containing disinfectants and toxic heavy metals, water containing organic pesticides and in situ treatment of natural waters for, e.g., river water with the help of floating pontoons. Biomass-related studies are also an open field of research as $P$. australis accumulates metal ions in the tissues, which on removal of the entire biomass raise a serious concern of its management.

\section{Conclusion}

In conclusion, $P$. australis is the most successful perennial grass species having a well-established regime with no specific boundaries (Fig. 1). The grass has adapted to most of the extreme environmental conditions, for e.g., extreme cold or extreme warmth as well as dryness or wetness.
Despite having a few environmental demerits such as invasiveness (which is still to be understood), scientists have proved its ability to restore the quality of environmental matrices. $P$. australis is used as a good source of roughage for cattle and the fibers for making paper (Mal and Narine 2004). Apart from these economic uses, $P$. australis is environmentally very sound. Research reports suggest the proven ability of $P$. australis to remove heavy metals cations, such as $\mathrm{Ni}, \mathrm{Cd}, \mathrm{Cu}$ and $\mathrm{Pb}$, and other nutrient anions, such as $\mathrm{PO}_{4}{ }^{3-}$ and $\mathrm{SO}_{4}{ }^{2-}$, from the aquatic environment. Phragmites spp. has enzymatic systems to degrade the xenobiotic organic compounds such as chlorinated pesticides and PCBs. It also helps maintain the oxygen level in water with the help of root-associated microbes.

Open Access This article is distributed under the terms of the Creative Commons Attribution License which permits any use, distribution, and reproduction in any medium, provided the original author(s) and the source are credited.

\section{References}

Aksoy A, Demirezen D, Duman F (2005) Bioaccumulation, detection and analysis of heavy metal pollution in Sultan Marsh and its environment. Water Air Soil Pollut 164:241-255

Al-Garni SMS (2006) Increasing NaCl-salt tolerance of a halophytic plant Phragmites australis by mycorrhizal symbiosis. J Agric Environ Sci 1(2):119-126

Ali NA, Bernal MP, Ater M (2002) Tolerance and bioaccumulation of copper in Phragmites australis and Zea mays. Plant Soil 239:103-111

Asaeda T, Manatunge J, Fujino T, Sovira D (2003) Effects of salinity and cutting on the development of Phragmites australis. Wetl Ecol Manag 11:127-140

Ayeni O, Ndakidemi P, Snyman R, Odendaal J (2012) Assessment of metal concentrations, chlorophyll content and photosynthesis in Phragmites australis along the lower Diep River, Cape Town, South Africa. Energy Environ Res 2(1):128-139

Batty LC, Baker AJM, Wheeler BD, Curtis CD (2000) The effect of $\mathrm{pH}$ and plaque on the uptake of $\mathrm{Cu}$ and $\mathrm{Mn}$ in Phragmites australis (Cav.) Trin ex Steudel. Ann Bot 86:647-653

Berk SG, Colwell RR (1981) Transfer of mercury through a marine microbial food web. J Exp Mar Biol Ecol 52:157-172

Bianchi V, Peruzzi E, Mascianclora G, Ceccanti B, Mora-Ravelo S, Iannelli R (2011) Efficiency assessment of a reed bed pilot plant (Phragmites australis) for sludge stabilization in Tuscany (Italy). Ecol Eng 37:779-785

Bonanno G (2011) Trace element accumulation and distribution in the organs of Phragmites australis (common reed) and biomonitoring applications. Ecotoxicol Enviorn Saf 74(4):1057-1064

Borin M, Milani M, Salvato M, Toscano A (2011) Evaluation of Phragmites australis (Cav.) Trin. evapotranspiration in Northern and Southern Italy. Ecol Eng 37:721-728

Bragato C, Brix H, Malagoli M (2006) Accumulation of nutrients and heavy metals in Phragmites australis (Cav.) Trin. ex. Steudel and Bolboschenus maritimus (L.) Palla in a constructed wetland of the Venice lagoon watershed. Environ Pollut 44(3):967-975

Bräutigam A, Hoffmann-Benning S (2008) Comparative proteomics of chloroplast envelops from $\mathrm{C} 3$ and $\mathrm{C} 4$ plants reveals specific

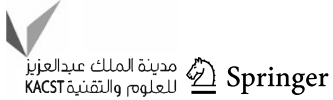


adaptations of plastid envelope to $\mathrm{C} 4$ photosynthesis and candidate protein. Plant Physiol 148:568-579

Brix H (1999) The European research project on reed die-back and progression (EUREED). Limnologica 29:5-10

Brix H, Schierup HH (1990) Soil oxygenation in constructed reed beds: The role of macrophyte and soil atmosphere interface oxygen transport. In: Cooper PF, Findlater BC (eds) Constructed wetlands in water pollution control. Pergamon Press, London, pp 53-66

Brix H, Arias CA, Johansen N (2003) Experiments in a two stage constructed wetland system: nitrification capacity and effects of recycling on nitrogen removal. In: Vymazal J (ed) Wetlands: nutrients, metals and mass cycling. Backhuys publisher, Leiden, pp 237-258

Burke DJ, Weis JS, Weis P (2000) Release of metals by the leaves of the salt marsh grasses Spartina alterniflora and Phragmites australis. Estuar Coast Shelf Sci 51:153-159

Caird MA, Richards JH, Donovan LA (2007) Nighttime stomatal conductance and transpiration in $\mathrm{C} 3$ and $\mathrm{C} 4$ plants. Plant Physiol 143:4-10

Carranza-Alvarez C, Alonso-Castro AJ, Alfaro-De La Torre MC, Garcia-De La cruz RF (2008) Accumulation and distribution of heavy metals in Scirpus americanus and Typha latifolia from an artificial lagoon in San Luis Potosi, Mexico. Water Air Soil Pollut 188:297-309

Chaturvedi S, Chandra R, Rai V (2006) Isolation and characterization of Phragmites australis (L.) rhizosphere bacteria from contaminated site for bioremediation of colored distillery effluent. Ecol Eng 27(3):202-207

Chiu KK, Ye ZH, Wong MH (2006) Growth of Vetiveria zizanioides and Phragmites australis on $\mathrm{Pb} / \mathrm{Zn}$ and $\mathrm{Cu}$ mine tailings amended with manure compost and sewage sludge: a greenhouse study. Bioresour Technol 97:158-170

Chu WK, Wong MH, Zhang J (2006) Accumulation, distribution and transformation of DDT and PCBs by Phragmites australis and Oryza sativa L.: II enzyme study. Environ Geochem Health 28:169-181

Clevering OA, Lissner J (1999) Taxonomy, chromosome numbers, clonal diversity and population dynamics of Phragmites australis. Aquat Bot 64:185-208

Clevering OA, Brix H, Lukavska J (2001) Geographic variations in growth responses in Phragmites australis. Aquat Bot 69:89-108

Cooper P (1999) A review of the design and performance of vertical flow and hybrid reed bed treatment systems. Water Sci Technol 40(3):1-9

Cooper PF, Job GD, Green MB, Shutes RBE (1996) Reed beds and constructed wetlands for wastewater treatment. WRc plc, Swindon

Coops H, Geilen N, Verheij HJ, Boeters R, van-der-Velde G (1996) Interactions between waves, bank erosion and emergent vegetation: an experimental study in a wave tank. Aquat Bot 53:187-198

da-Motta-Marques DML, Leite GR, Giovannini SGT (2001) Performance of two macrophyte species in experimental wetlands receiving variable loads of anaerobically treated municipal wastewater. Water Sci Technol 44(11-12):311-317

Derner JD, Johnson HB, Kimball BA, Pinter PJ Jr, Polley HW, Tischler CR, Buttons TW, Lomorte RL, Wall GW, Adam NR, Leavitt SW, Ottman MJ, Matthias AD, Brooks TJ (2003) Above and below-ground responses of $\mathrm{C} 3-\mathrm{C} 4$ species mixtures to elevated $\mathrm{CO}_{2}$ and water availability. Glob Change Biol 9:452-460

Dinka M, Szeglet P (1998) Reed (Phragmites australis (Cav.) Trin. ex. Steudel) growth and production in different habitats of Neusiedlresee (Lake Fert) Verh. Internationale Vereinigung für Theoretische und Angewandte Limnologie 26:1830-1834
Drzewiecka K, Borowiak K, Mieczek M, Zawada I, Golinski P (2010) Cadmium and lead accumulation in two plants of five lakes in Poznan, Poland. Acta Biologica Cracoviensia 52(2):59-68

Duan XN, Wang XK, Ouyang ZY (2009) Influence of common reed (Phragmites australis) on $\mathrm{CH}_{4}$ production and transport in wetlands: results from single-plant laboratory experiments. Water Air Soil Pollut 197:185-191

Edwards EJ, McCaffery S, Evans JR (2005) Phosphorus status determines biomass response to elevated $\mathrm{CO}_{2}$ in a legume: $\mathrm{C} 4$ grass community. Glob Change Biol 11:1968-1981

Ekstam B, Johannesson R, Milberg P (1999) The effect of light and number of diurnal temperature fluctuations on germination of Phragmites australis. Seed Sci Res 9:165-170

Evans LT (1993) Crop evolution, adaptation and yield. Cambridge University Press, Cambridge

Garcia J, Aguirre P, Mueriego R, Hung Y, Ortiz L, Bayona JM (2004) Initial contamination removal performance factor in horizontal flow reed beds used for treating urban wastewater. Water Res 38:1669-1678

Ghassemzadeh F, Yousefzadeh H, Arbab-Zavar MH (2008) Removing arsenic and antimony by Phragmites australis: rhizofiltration technology. J Appl Sci 8(9):1668-1675

Gorai M, Ennajeh M, Khemira M, Neffati M (2010) Combined effect of $\mathrm{NaCl}$-salinity and hypoxia on growth, photosynthesis, water relations and solute accumulation in Phragmites australis plants. Flora 205:462-470

Greenway M, Wooley A (1999) Constructed wetlands in Queensland: performance efficiency and nutrient bioaccumulation. Ecol Eng 12:39-55

Greenwood ME, MacFarlane GR (2006) Effects of salinity and temperature on the germination of Phragmites australis, Juncus kraussii, and Juncus acutus: implications for estuarine restoration initiatives. Wetlands 26(3):854-861

Greipsson S (1994) Effects of iron plaque on roots of rice on growth and metal concentration of seeds and plant tissues when cultivated in excess copper. Commun Soil Sci Plant Anal 25:2761-2769

Häfliger P, Schwarzlander M, Blossey B (2006) Impact of Archanara geminipuncta (Lepidoptera: Noctuidae) on aboveground biomass production of Phragmites australis. Biol Control 38:413-421

Hara T, van-der-Troon J, Mook JH (1993) Growth dynamics and size structure of shoot of Phragmites australis, a clonal plant. J Ecol $81: 47-60$

Hartzendorf T, Rolletschek H (2001) Effects of NaCl-salinity on amino acid and carbohydrate content of Phragmites australis. Aquat Bot 69:195-208

Haslam SM (1972) Biological flora of the British Isles No. 128: Phragmites communis Trin. J Ecol 60:585-610

Kadlec RH, Knight RL (1996) Treatment wetlands. CRC Press, Boca Raton

Kankaala P, Ojala A, Käki T (2004) Temporal and spatial variation in methane emissions from a flooded transgression shore of a boreal lake. Biogeochemistry 68:297-311

Kaseva ME (2004) Performance of a sub-surface flow constructed wetland in polishing pre-treated wastewater: a tropical case study. Water Res 38:681-687

Keller B, Lajth K, Cristofer S (1998) Trace metal concentrations in the sediments and plants of the Danube delta, Romania. Wetland 18:42-50

Kenneth RG, Biddlestone AJ (1995) Engineered reed bed systems for waste water treatment. Trends Biotechnol 13:248-252

Kettenring KM, McCormick MK, Baron HM, Whigham DF (2010) Phragmites australis (common reed) invasion in the Rhode River sub-estuary of Chesapeake Bay: disentangling the effects of foliar nutrients, genetic diversity, patch size, and seed viability. Estuaries Coasts 33:118-126 
Knight RL, Payne-Jr VWF, Borer RE, Clarke-Jr RA, Pries JH (2000) Constructed wetlands for livestock wastewater management. Ecol Eng 15(1-2):41-55

Lee B, Scholz M (2007) What is the role of Phragmites australis in experimental constructed wetland filters treating urban runoff? Ecol Eng 29:87-95

Lessmann JM, Brix H, Bauer V, Clevering OA, Comin FA (2001) Effect of climatic gradients on the photosynthetic responses of four Phragmites australis populations. Aquat Bot 69:109-126

Li HY, Zhu JN, Zhai ZH, Zhang Q (2010) Endophytic bacterial diversity in roots of Phragmites australis in constructed Beijing Cuihu wetland (China). FEMS Microbiol Lett 309:84-93

Li HY, Zhu JN, Liu OF, Liu Y, Liu M, Liu L, Zhang Q (2013) Comparison of the diversity of root associated bacteria in Phragmites australis and Typha angustifolia L. in artificial wetlands. World J Microbiol Biotechnol. doi:10.1007/s11274013-1316-2

Lissner J, Schierup HH, Comin FA, Astorga V (1999) Effect of climate on the salt tolerance of two Phragmites australis populations, I. growth, inorganic solutes, nitrogen relations and osmoregulation. Aquat Bot 64:317-333

Mal TK, Narine L (2004) The biology of Canadian weeds. 129. Phragmites australis (Cav.) Trin. ex Steud. Can J Plant Sci 84:365-396

Mant C, Costa S, Williams J, Tambourgi E (2006) Phytoremediation of chromium by model constructed wetland. Bioresour Technol 97:1767-1772

Marks M, Lapin B, Randall J (1994) Phragmites australis ( $P$. communis) threat, management and monitoring. Nat Areas $\mathrm{J}$ 14:285-294

Meyerson LA, Saltonstall K, Windham L, Kiviat E, Findlay CS (2000) A comparison of Phragmites australis in fresh water and brackish marsh environments in North America. Wetl Ecol Manag 8:89-113

Nechwatal J, Wielgoss A, Mendgen K (2008) Flooding events and rising water temperatures increase the significance of the reed pathogen Pythium phragmitis as a contributing factor in the decline of Phragmites australis. Hydrobiologia 613:109-115

Nimptsch J, Pflugmacher S (2007) Ammonia triggers the promotion of oxidative stress in the aquatic macrophyte Myriophyllum mattogrossense. Chemosphere 66:708-714

Niu S, Zhang Y, Yuan Z, Liu W, Huang J, Wan S (2006) Effects of interspecific competition and nitrogen seasonally on the photosynthetic characteristics of $\mathrm{C}_{3}$ and $\mathrm{C}_{4}$ grasses. Environ Exp Bot 57:270-277

Nixdorf B, Fyson A, Krumbeck H (2001) Review: plant life in extremely acidic waters. Environ Exp Bot 46:203-211

Okabe S, Nakamura Y, Satoh H (2012) Community structure and in situ activity of nitrifying bacteria in Phragmites rootassociated biofilms. Microbes Environ 27(3):242-249

Oliveira RS, Dodd JC, Castro PML (2001) The mycorrhizal status of Phragmites australis in several polluted soils and sediments of an industrialized region of Northern Portugal. Mycorrhiza 10:241-247

Ostendorp W, Tiedge E, Hille S (2001) Effect of eutrophication on culm architecture of lakeshore Phragmites reeds. Aquat Bot 69:177-193

Ostendorp W, Dienst M, Schmieder K (2003) Disturbance and rehabilitation of lakeside Phragmites reeds following an extreme flood in Lake Constance (Germany). Hydrobiologia 506-509:687-695

Pagter M, Bragato C, Malagoli M, Brix H (2009) Osmotic and ionic effects of $\mathrm{NaCl}$ and $\mathrm{Na}_{2} \mathrm{SO}_{4}$ salinity on Phragmites australis plants. Aquat Bot 90:43-51

Peltier EE, Webb SM, Gaillard J (2003) Zinc and lead sequestration in an impacted wetland system. Adv Environ Res 8:103-112
Poonawala IS, Jana MM, Nadgauda RS (1999) Factors influencing bud break and rooting and mass scale micropropogation of three Phragmites species: P. karka, P. communis and P. australis. Plant Cell Rep 18:696-700

Roman CT, Niering WA, Warren RS (1984) Salt marsh vegetation change in response to tidal restriction. Environ Manag $8: 141-150$

Rudrappa T, Bonsall J, Gallagher JL, Seliskar DM, Bais HP (2007) Root-secreted allelochemical in the noxious weed Phragmites australis deploys a reactive oxygen species response and microtubule assembly disruption to execute rhizotoxicity. J Chem Ecol 33:1898-1918

Sage RF (2004) The evolution of $\mathrm{C}_{4}$ photosynthesis. New Phytol 161:341-370

Saltonstall K (2002) Cryptic invasion by a non-native genotype of the common reed, Phragmites australis, into North America. Proc Natl Acad Sci USA 99:2445-2449

Samecka-Cymerman A, Kempers AJ (2001) Concentrations of heavy metals and plant nutrients in water, sediments and aquatic macrophytes of anthropogenic lakes (former open cut brown coal mines) differing in stage of acidification. Sci Total Environ 281:87-98

Schierup HH, Larsen VJ (1981) Macrophyte cycling of zinc, copper, lead and cadmium in the littoral zone of a polluted and a non polluted lake. I. Availability, uptake and translocation of heavy metals in Phragmites australis (Cav.) Trin. Aquat Bot 11:197-210

Scholz M (2003) Performance predictions of mature experimental constructed wetlands which treat urban water receiving high loads of lead and copper. Water Res 37:1270-1277

Scholz M, Xu J (2002) Performance comparison of experimental constructed wetlands with different filter media and macrophytes treating industrial wastewater contaminated with lead and copper. Bioresour Technol 83:71-79

Singh N, Srivastava JK (2007) Comparison of the ability of two grasses viz., Phragmites karka (Retz.) Trin. Ex. Steud and Vetiveria zizanioides (L.) Nash to improve surface water quality in a constructed wetland. Int J Water 3(3):266-274

Small E, Catling PM (2001) Poorly known economic plants of Canada: 29. Common reed, Phragmites australis (Cav.) Trin. ex Steud. Can Bot Assoc Bull 34:21-26

Solano ML, Soriano P, Ciria MP (2004) Constructed wetlands as a sustainable solution for wastewater treatment in small villages. Bioprocess Biosyst Eng 87(1):109-118

Southichak B, Nakano K, Nomura M, Chiba N, Nishimura O (2006) Phragmites australis: a novel biosorbent for the removal of heavy metals from aqueous solution. Water Res 40:2295-2302

Srinivasan N, Weaver RW, Lesikar BJ, Persyn RA (2000) Improvement of domestic wastewater quality by subsurface flow constructed wetlands. Bioresour Technol 75(1):19-25

Srivastava J (2008) Sustainable mitigation of pollution from pond ecosystem through aquatic plants and microbial intervention. Ph.D. Thesis University of Lucknow UP India

Srivastava J, Gupta A, Chandra H (2008) Managing water quality with aquatic macrophytes. Rev Environ Sci Bio/Technol 7:255-266

Srivastava J, Kalra SJS, Shukla K (2011) Action of cations on the leachability of bio-stimulants in a soil column at soil-water interface and its impact on surface water quality. Int J Hydrol Sci Technol 1(3/4):252-259

Srivastava J, Kalra SJS, Chandra H, Nautiyal AR (2012) Response of $\mathrm{C}_{3}$ and $\mathrm{C}_{4}$ plant systems exposed to heavy metals for phytoextraction at elevated atmospheric $\mathrm{CO}_{2}$ and at elevated temperature. In: Jatin K, Srivastava J (eds) Environmental contamination. Intech open Publisher, Croatia, pp 3-16 
St-Cyr L, Crowder AA (1988) Iron oxide deposition on the roots of Phragmites australis related to the iron bound to carbonates in the soil. J Plant Nutr 11:1253-1262

Stottmeister U, Wießner A, Kuschk P, Kappelmeyer U, Kästner M, Bederski O, Müller RA, Moormann H (2003) Effects of plant and microorganisms in constructed wetlands for wastewater treatment. Biotechnol Adv 22:93-117

Subbaiah C, Sachs M (2003) Molecular and cellular adaptations of maize to flooding stress. Ann Bot 91:119-127

Szymanowska A, Samecka-Cymerman A, Kempers AJ (1999) Heavy metals in three lakes in west Poland. Ecotoxicol Environ Saf 43:21-29

Takahashi R, Nishio T, Ichizen N, Takano T (2007) Salt tolerant reed plants contain lower $\mathrm{Na}^{+}$and higher $\mathrm{K}^{+}$than salt sensitive reed plants. Acta Physiol Plant 29:431-438

Tang J, Xu L, Chen X, Hu S (2009) Interaction between $\mathrm{C}_{4}$ barnyard grass and $\mathrm{C}_{3}$ upland rice under elevated $\mathrm{CO}_{2}$ : impact of mycorrhizae. Acta Oecol 35:227-235

Toet S, Van-Logtestijn RSP, Schrijer M, Kampf R, Verhoeven JTA (2005) The functioning of a wetland system used for polishing effluent from a sewage treatment plant. Ecol Eng 25:101-124

Toyama T, Furukawa T, Maeda N, Inoue D, Sei K, Mori K, Kikuchi S, Ike M (2011a) Accelerated biodegradation of pyrene and benzo[a]pyrene in the Phragmites australis rhizosphere by bacteria-root exudate interactions. Water Res 45(4):1629-1638

Toyama T, Murashita K, Kobayashi K, Kikuchi S, Sei K, Tanaka Y, Ike M, Mori K (2011b) Acceleration of nonylphenol and 4-tertoctylphenol degradation in sediment by Phragmites australis and associated rhizosphere bacteria. Environ Sci Technol 45(15):6524-6530

Treseder KK (2004) A meta-analysis of mycorrhizal responses to nitrogen, phosphorus, and atmospheric $\mathrm{CO}_{2}$ in field studies. New Phytol 164:347-355

Ueno $\mathrm{O}$ (2001) Environmental regulation of $\mathrm{C}_{3}$ and $\mathrm{C}_{4}$ differentiation in the amphibious sedge Eleocharis vivipara. Plant Physiol 127:1524-1532

Vymazal J, Kropfelova L (2005) Growth of Phragmites australis and Phalaris rundinaceae in constructed wetland for wastewater treatment in the Czech Republic. Ecol Eng 25(5):606-621

Wand SJ, Midgley GF, Jones MH, Curtis PS (1999) Response of wild $\mathrm{C}_{4}$ and $\mathrm{C}_{3}$ (Poaceae) species to elevated atmospheric $\mathrm{CO}_{2}$ concentration: a meta-analytic test of current theories and perceptions. Glob Change Biol 5:723-741
Wang J, Seliskar DM, Gallagher JL, League MT (2006) Blocking Phragmites australis reinvasion of restored marshes using plants selected from wild population and tissue culture. Wetl Ecol Manag 14:539-547

Wang H, Jia YF, Liu L, Zhu HJ, Wu X, Wang SY (2009) Bioavailability of absorbed $\mathrm{Cd}$ on typical oxides of sediments in Phragmites australis. (In Chinese) Huanjing Kexue Chin J Environ Sci 30(6):1773-1778

Wang R, Korboulewsky N, Prudent P, Domeizel M, Ronaldo C, Bonin G (2010) Feasibility of using an organic substrate in a wetland system treating sewage sludge: impact of plant species. Bioresour Technol 101(1):51-57

Weber APM, Caemmerer SV (2010) Plastid transport and metabolism of $\mathrm{C}_{3}$ and $\mathrm{C}_{4}$ plants comparative analysis and possible biotechnological exploration. Curr Opin Plant Biol 13:257-265

Weidenhamer JD, Li M, Allman J, Bergosh RG, Posner M (2013) Evidence does not support a role for Gallic acid in Phragmites australis invasion success. J Chem Ecol. doi:10.1007/s10886013-0242-y

Weis JS, Weis P (2004) Metal uptake, transport and release by wetland plants: implications for phytoremediation and restoration. Environ Int 30:685-700

Weisner SEB, Strand JA (1996) Rhizome architecture in Phragmites australis in relation to water depth: implications for within-plant oxygen transport distances. Folia Geobotanica Phytotaxonomica 31:91-97

Windham L, Weis JS, Weis P (2001) Patterns and processes of mercury release from leaves of two dominant salt marsh macrophytes Phragmites australis and Spartina alterniflora. Estuaries 24(6A):787-795

Winslow JC, Hunt-Jr ER, Piper SC (2003) The influence of seasonal water availability on global $\mathrm{C}_{3}$ versus $\mathrm{C}_{4}$ grassland biomass and its implications for climate change research. Ecol Model 163:153-173

Ye ZH, Baker AJM, Wong MH, Willis AJ (2003) Copper tolerance, uptake and accumulation by Phragmites australis. Chemosphere 50:795-800

Zheng WJ, Zheng XP, Zhang CL (2000) A survey of photosynthetic carbon metabolism in 4 ecotypes of Phragmites australis in northwest China: leaf anatomy, ultra-structure, and activities of ribulose 1,5-biphosphate carboxylase, phosphoenolpyruvate carboxylase and glycolate oxidase. Physiol Plant 110:201-208 